\title{
Spatial distribution analysis of Dicksonia sellowiana Hook. in Araucaria forest fragments with different sizes
}

\author{
I. T. Mallmann ${ }^{a *}$, V. L. Silva ${ }^{a, b}$, R. K. Port ${ }^{a}$, F. B. Oliveira ${ }^{a}$ and J. L. Schmitt ${ }^{a}$ \\ ${ }^{\text {a}}$ Laboratório de Botânica, Universidade Feevale, Rodovia Estadual ERS-239, 2755, \\ Novo Hamburgo, RS, Brasil \\ 'Instituto de Ecología, Asociación Civil - A.C., Red de Ecología Funcional, Carretera antigua a Coatepec, 351, \\ El Haya, Xalapa 91070, Veracruz, México \\ *e-mail: ivamallmann@terra.com.br
}

Received: October 2, 2017 - Accepted: November 8, 2017 - Distributed: May 31, 2019

(With 3 figures)

\begin{abstract}
Dicksonia sellowiana Hook. (Dicksoniaceae) is target of extractive exploitation and is threatened with extinction. We analyzed the population structure, the spatial distribution pattern of $D$. sellowiana and its relationship with environmental parameters within three fragments of Araucaria Forest in Rio Grande do Sul, Brazil. The fragments are of different sizes, namely, large (H1LF) with 246 ha, medium (H2MF) with 57 ha and small (H3SF) with 5.2 ha. Within each site, 1 ha was delimited, divided into 100 subplots $\left(100 \mathrm{~m}^{2}\right)$, of which 20 were selected with a draw. In each subplot, counting of the individuals, the registration of the caudice height and the coverage of leaves (SC) $\left(\mathrm{m}^{2}\right)$, measurements of photosynthetically active radiation (PAR), canopy opening degree (CO), soil moisture (SM) and litter thickness (LT). The temperature $(\mathrm{T})$ was measured inside each site. A total of 792 plants were sampled, of which 551 were concentrated in H1LF, 108 in H2MF and 133 in H3SF. An average of 1320 ha $^{-1}$ individuals were estimated. Of the total including the three fragments, $96.9 \%$ of the individuals are in the first class of height (up to $0.8 \mathrm{~m}$ ), indicating a great potential of population development. The spatial distribution pattern (AI) was aggregated in the three populations and the plants presented a heterogeneous total coverage, between $4.73 \mathrm{~m}^{2}$ (H2MF) and 2,223.47 $\mathrm{m}^{2}$ (H1LF). The highest values of $\mathrm{SC}$ and SM were more related to the distribution of individuals in H1LF whereas the opposite was recorded in H2MF. The highest values of PAR, LT and CO correlated with the distribution of D. sellowiana in H3SF. In addition to revealing that the H1LF population is among the most dense in southern Brazil, the results demonstrated a significant structural distinction between the interior populations of the fragments, in spite of them being located near to one another and being part of the same natural field matrix.
\end{abstract}

Keywords: fragments, bioindicators, environmental variables, canopy opening.

\section{Análise da distribuição espacial de Dicksonia sellowiana Hook. em fragmentos de Floresta com Araucária com diferentes tamanhos}

\section{Resumo}

Dicksonia sellowiana Hook. (Dicksoniaceae) é alvo de exploração extrativista e encontra-se ameaçada de extinção. Analisamos a estrutura populacional, o padrão de distribuição espacial de $D$. sellowiana e sua relação com parâmetros ambientais no interior de três fragmentos de Floresta com Araucária, no Rio Grande do Sul (RS), Brasil. Os fragmentos possuem diferentes tamanhos sendo denominados de grande (H1LF) com 246 ha, médio (H2MF) com 57 ha e de pequeno (H3SF) com 5,2 ha. No interior de cada sítio, foi demarcado 1 ha, fracionado em 100 subparcelas $\left(100 \mathrm{~m}^{2}\right)$, das quais 20 foram sorteadas. Em cada subparcela foi feita a contagem dos indivíduos, o registro da altura do cáudice e da cobertura $(\mathrm{SC})\left(\mathrm{m}^{2}\right)$ das folhas, as medições da radiação fotossinteticamente ativa (PAR), grau de abertura do dossel (CO), umidade do solo (SM) e espessura da serapilheira (LT). A temperatura ( $\mathrm{T}$ ) foi medida no interior de cada sítio. Foram amostradas 792 plantas, das quais 551 concentradas no H1LF, 108 no H2MF e 133 no H3SF e em média foram estimados 1320 indivíduos ha ${ }^{-1}$. Do total dos três fragmentos, 96,9\% dos indivíduos estão na primeira classe de altura (até $0,8 \mathrm{~m}$ ), indicando grande potencial de desenvolvimento das populações. O padrão de distribuição espacial (AI) foi agregado nas três populações e as plantas apresentaram uma cobertura total heterogênea, entre $4,73 \mathrm{~m}^{2}(\mathrm{H} 2 \mathrm{MF})$ e $2.223,47 \mathrm{~m}^{2}$ (H1LF). Os maiores valores de SC e de SM foram mais relacionadas com a distribuição dos indivíduos no H1LF enquanto que o contrário foi registrado no H2MF. Os maiores valores de PAR, LT e de CO relacionaram-se com a distribuição de D. sellowiana no H3SF. Além de revelar que a população do H1LF está entre as mais densas 
já descritas no sul do Brasil, os resultados demonstraram uma significativa distinção estrutural entre as populações dos interiores dos fragmentos com diferentes tamanhos, embora muito próximos geograficamente e inseridos em uma mesma matriz de campo natural.

Palavras-chave: fragmentos, bioindicadores, varávies ambientais, abertura de dossel.

\section{Introduction}

The arborescent fern Dicksonia sellowiana Hook. (Dicksoniaceae), also known as Xaxim, is the subject of extractive exploitation. It is listed in the Brazilian List of Flora Species Threatened by Extinction in accordance with MMA Ordinance N. 443 of December 17, 2014 (Ministério do Meio Ambiente, 2014) and in the List of Endangered Native Flora Species of Extinction in the State of RS, Decree N. 52.109/2014 (Fundação Zoobotânica do Rio Grande do Sul, 2014). This species occurs from southern Mexico in North America, in Central America, in Venezuela, Colombia, southern Bolivia, Paraguay, Uruguay and Brazil in South America (Tryon and Tryon, 1982). In Brazil, this fern is found in the south and southeast regions in the states of Minas Gerais, São Paulo, Rio de Janeiro, Paraná, Santa Catarina and Rio Grande do Sul (Rio de Janeiro, 2016). In Southern Brazil, it is one of the most characteristic plants of the Araucaria Forest (AF) subforest (Oliveira et al., 2013), which is a unique type of plant formation in the whole world (Koch and Corrêa, 2002).

Recently, it was observed that, on a local scale, D. sellowiana promotes biological diversity by increasing habitat heterogeneity. It facilitates the coexistence of species both by inhibiting the dominance of some woody plants and by providing habitat for the establishment of epiphytes and hemiepiphytes, which enlarges the diversity of plants in the forest (Negrão et al., 2017). Due to the presence of a porous mass of adventitious roots that holds great humidity (Cortez, 2001), the species is fundamental to the reproductive success of ferns (Becker et al., 2015) and constitutes an exclusive (Becker et al., 2015; Mallmann and Schmitt, 2014) or preferential microhabitat for some species (Schmitt et al., 2005; Cortez, 2001).

The capacity of $D$. sellowiana on carbon sequestration (11.92 $\left.\mathrm{t} \mathrm{ha}^{-1}\right)$ is relevant, reaching values close to those recorded for native tree species in Araucaria Forests in Paraná (Ziemmer et al., 2016). In addition, it can add a large amount of organic matter to the soil (Fraga et al., 2008). In relation to the potential of economic and pharmacological use, new perspectives arise with the description of the antioxidant properties of the extract obtained from the leaves of this species. The tests did not show toxicity for the in vitro models. Therefore, they could be used in the treatment of cardiovascular, neurodegenerative and anti-aging diseases (Oliveira et al., 2015). In popular medicine, its use has older records (Corrêa, 1984).

Until 2000, D. sellowiana was part of an intense economic cycle of exploration (Windisch, 2002; Biondi et al., 2009), which, added to the slow growth of these plants, to the continuity of the illegal extraction of forest remnants (Schmitt et al., 2009) and the destruction of the natural habitat (Biondi et al., 2009), contributes to its vulnerability. In addition, to assess the susceptibility of the species to a future scenario, it is necessary to consider the effects of global warming, which should significantly reduce areas for the natural occurrence of this fern, even in the most optimistic climate prospects (Medeiros et al., 2013).

Among the environmental variables, soil moisture is cited as the most important for the high density and plant coverage (Fraga et al., 2008; Blume et al., 2010; Gasper et al., 2011). Temperature is also predominant in the distribution of $D$. sellowiana. The altitude (above 1,000 m) and the associated temperature variation, too, influence the population directly (Gasper et al., 2011). The coldest regions are the most favorable for the development of D. sellowiana. At the local scale, the largest occurrence of individuals is verified within a specific forest environment, with a conserved structure and sufficient extension to ensure different microenvironments (Mantovani, 2004).

It is imperative to intensify studies on the ecological, biological, structural and dynamic aspects of the species in this habitat type to obtain more enlightening results on its development (Weber et al., 2015). In this context, the objectives of this study were: (1) to analyze the population structure of D. sellowiana; (2) to verify the relation of the structure of the populations with soil moisture, litter, temperature, photosynthetically active radiation (PAR) and canopy opening; (3) determine the spatial distribution pattern of the species.

\section{Material and Methods}

Study site: The study was carried out in three sites located within fragments of Araucaria Forest, in Aparados da Serra National Park (PNAS), Cambará do Sul (2907'58.53”S e 5006'18.89'O, 1024 m altitude), in Rio Grande do Sul, Brazil (Figure 1). The regional climate according to the Köeppen-Geiger classification is of the Cfb type (Peel et al., 2007). The soil is shallow to deep, classified as an aluminum humid cambisol, associated with a litolical nucleus. High rainfall and low temperatures favor the accumulation of organic matter in the region (Streck et al., 2008). The three forest fragments of the study are part of a matrix habitat composed of natural field and are of different sizes. The large fragment (LF) has a total area of 246 ha $\left(29^{\circ} 08^{\prime} 04.09^{\prime}\right.$ S e $\left.50^{\circ} 07^{\prime} 06.86^{\prime \prime} \mathrm{W}\right)$, the medium (MF) has a total area of 57 ha $\left(29^{\circ} 07^{\prime} 10.43^{\prime \prime} \mathrm{S}\right.$ e $\left.50^{\circ} 06^{\prime} 54.53^{\prime \prime} \mathrm{W}\right)$ and the small (SF) of 5.2 ha $\left(29^{\circ} 07^{\prime} 58.70^{\prime \prime} \mathrm{S}\right.$ e $\left.50^{\circ} 06^{\prime} 17.89^{\prime \prime} \mathrm{W}\right)$. The sites are named H1LF, H2MF and H3SF, respectively.

Sampling and analysis of the population structure: During one year (from June 2015 through June 2016), periodic expeditions to the sample units were carried out in order to perform the floristic inventory and the 


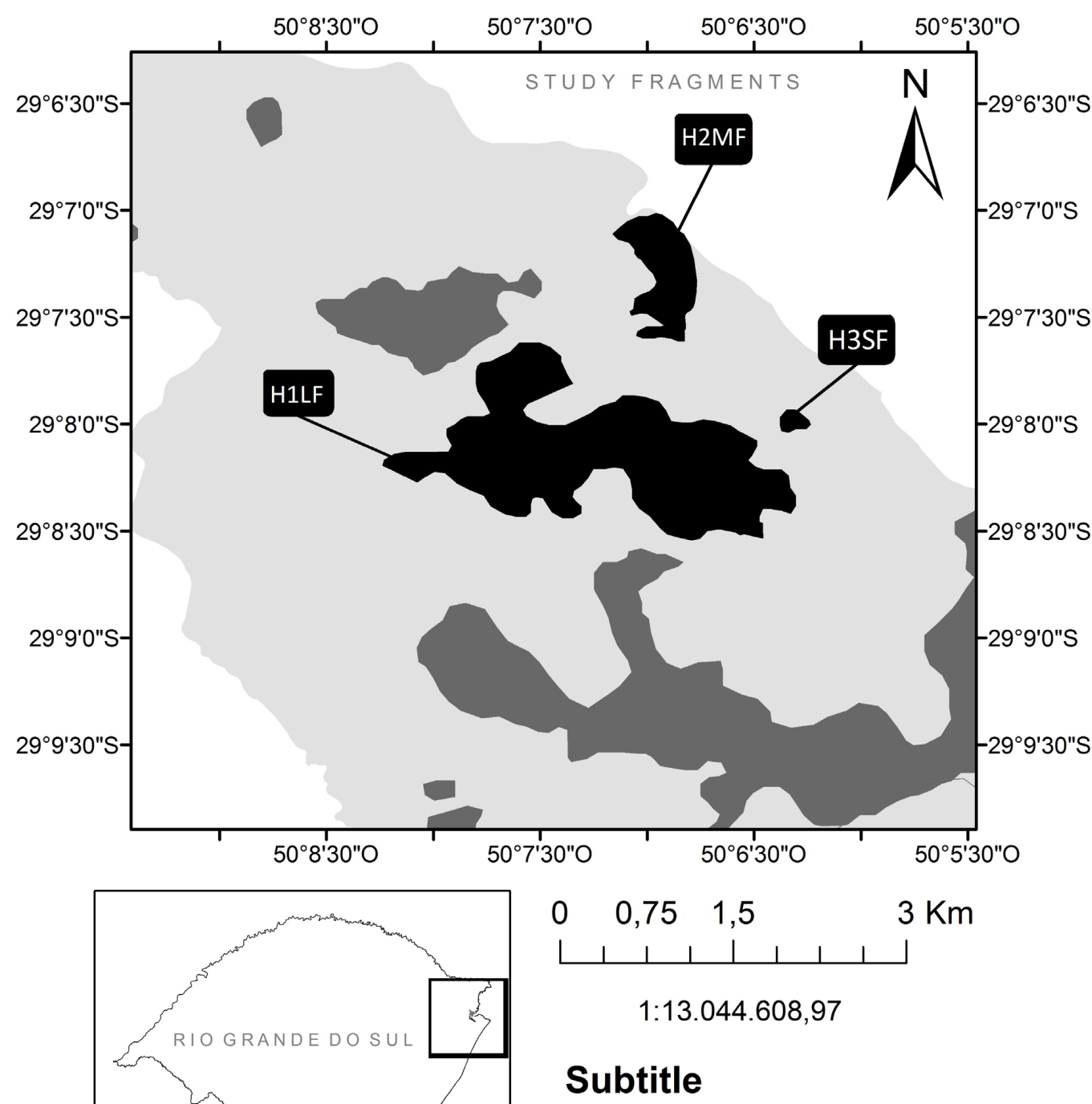

Araucaria forest

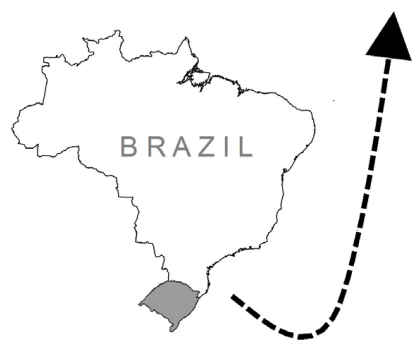

\section{Non-forest (Natural field) \\ Study area}

Figure 1. Map of the study fragments in Araucaria Forest at Parque Nacional de Aparados da Serra (PNAS), where the H1LF, H2MF and H3SF sites are located. Source: SOS Mata Atlântica (2015), IBGE (2016). Prejection: UTM. Coordinate System: SIRGAS 2000. Prepared by Fernando Bertoldi de Oliveira.

data collection of environmental variables. Sampling units are $100 \times 100 \mathrm{~m}(1 \mathrm{ha})$ plots fractionated into 100 subplots of $10 \times 10 \mathrm{~m}\left(100 \mathrm{~m}^{2}\right)$. Of these, 20 units were randomly selected, totaling $2000 \mathrm{~m}^{2}$ sampled in each site. For the analysis of the population structure and the spatial distribution pattern of Dicksonia sellowiana, 
the individuals were counted in each subplot, the record of the height of the caudices and coverage $\left(\mathrm{m}^{2}\right)$ of the plants was done, as well as an estimate of individuals per ha. In order to characterize the vertical structure, the individuals were organized into vertical classes of size, using $0.8 \mathrm{~m}$ height intervals, as adopted by Schmitt and Windisch (2007): 0 to $0.8 \mathrm{~m}$ (Class 1 ), $>0.8$ to $1.6 \mathrm{~m}$ (Class 2), > 1.6 to $2.4 \mathrm{~m}$ (Class 3 ), $>2.4$ to $3.2 \mathrm{~m}$ (Class 4 ), $>3.2$ to $4.0 \mathrm{~m}$ (Class 5$),>4.0$ to $4.8 \mathrm{~m}$ (Class 6$),>4.8$ to $5.6 \mathrm{~m}$ (Class 7), > 5.6 to $6.4 \mathrm{~m}$ (Class 8), 6.4 to $7.2 \mathrm{~m}$ (Class 9), and 7.2 to $8.0 \mathrm{~m}$ (Class 10$)$. All individuals with caudex heights equal to or less than $80 \mathrm{~cm}$ were considered as young and sterile, and all individuals with caudex heights greater than $80 \mathrm{~cm}$ were considered adults and fertile.

Environmental variables: the photosynthetically active radiation (PAR) measurements were performed at the center of each subplot of the three sites for one minute by using a LI-COR Line Quantum Sensor LI-190, located on a stand, $1 \mathrm{~m}$ from the ground and coupled to a DataLogger (LI-1400) LI-COR. Five repetitions at one-hour intervals were made between 10 and $2 \mathrm{pm}$ the same day in all three sites.

The canopy opening degree was obtained from hemispheric photos of the forest interior, in the center of each subplot. The photos were taken with the camera leveled and positioned to the north, $1 \mathrm{~m}$ of the ground according to the technique described by Garcia et al. (2007). A Sony H5 model camera was used, coupled to a Raynox Digital fisheye lens model DCR-CF 85 Pro. Images were examined in the Image J $1.5 \mathrm{i}$ software to obtain the canopy opening percentage.

Soil moisture was measured with the Moisture Meter (model HH2 - AT Delta - TDevices, version 4.0), from which the information can be read directly. The litter thickness in $(\mathrm{cm})$ was measured using a $30 \mathrm{~cm}$ ruler. Both pieces of information were diagonally recorded at three points of each subplot.

At each site, data referring to temperature were recorded on a typical winter day in 2015 and a typical summer day in 2016, every hour for 11 consecutive hours (from 8 a.m. to 6 p.m.), at the three forest sites simultaneously. A Thermo-hygro-anenometer (Instruterm-Thal-300, model 0211) was used for this purpose. The other environmental variables were all measured in the spring of 2016.

\section{Analytical Procedures}

\subsection{Analysis of environmental variables}

Data were submitted to the Shapiro-Wilk normality test for the analyses of environmental variables. Those that met the normality assumption were compared by variance analysis (ANOVA), followed by the Tukey test, at 5\% probability. Data that did not present normal distribution were analyzed by Kruskal-Wallis non-parametric test, followed by the Mann Wittney test, at 5\% probability.

A Principal Component Analysis (PCA) was performed to verify if there was variation in the distribution and coverage of the Dicksonia sellowiana individuals of the three sites related to the environmental variables (photosynthetically active radiation, canopy opening, temperature, soil moisture and litter). These analyzes were conducted in the Paleontological Statistics Package for Education and Data Analysis (PAST), version 3.1.

The spatial distribution of individuals was described using the variance/average ratio (R) (Krebs, 1989). The chi-square test $\left(X^{2}\right)$, at a significance level of $5 \%$, was used to evaluate the dispersion index. Values of $\mathrm{R}$ lower than 1.0 indicate uniform distribution, equal to 1.0 random distribution and greater than 1.0 pooled distribution.

\subsection{Results}

In the $6,000 \mathrm{~m}^{2}$ of the three sites, 792 individuals were sampled, and the highest abundance was recorded in the H1LF, which concentrated $69.6 \%$ of the total (551), while in $\mathrm{H} 2 \mathrm{MF}$ and H3SF 108 and 133 individuals occurred, respectively. The average number of individuals per subplot decreased from H1LF to H3SF (Table 1). The species was recorded in 54 of the 60 sample units, that is, at a frequency of $90 \%$. In the H1LF subplots the frequency was $100 \%$, in $\mathrm{H} 2 \mathrm{MF}$ it was $75 \%$ and in $\mathrm{H} 3 \mathrm{SF}$ it was $95 \%$.

The density estimation for a 1-hectare area, considering the three sites ( $0.6 \mathrm{ha}$ ) resulted in 1,320 individuals ha ${ }^{-1}$. When the sites were considered in isolation, the density estimation corresponded to 2,755 individuals $\mathrm{ha}^{-1}$ in H1LF, 540 in H2MF and 665 in H3SF.

Regarding the caudice height, the three sites recorded a high percentage of individuals $(97.1 \%)$ in the first interval (0 - 0.8m), 94.3\% in H1LF, 100\% in H2MF and $96.9 \%$ in H3SF (Figure 2). The average height was $31.3 \mathrm{~cm}, 1.6 \mathrm{~cm}$ and $20.3 \mathrm{~cm}$, respectively. The largest sampled specimen measured $8 \mathrm{~m}$ (in H1LF) and the lowest measured $1 \mathrm{~cm}$ (recorded in all three sites).

The intensity of Dicksonia sellowiana pooling was different in fragments of different sizes, though, all three groups showed a pooled distribution pattern, which was higher in H2MF (AI $\left.=10.2, X^{2}=193.85\right)$ compared to populations with adult individuals $(\mathrm{H} 1 \mathrm{LF} \mathrm{AI}=8.82$ $X^{2}=167.72$, and H3SF AI $\left.=4.1 X^{2}=77.97\right)$.

Table 1. Number of Dicksonia sellowiana individuals (ind.) with their respective sites (H1LF; H2MF; H3SF) occurrence and height intervals (m).

\begin{tabular}{rccc}
\hline Scale & H1LF & H2MF & H3SF \\
\hline $0-0.8$ & 520 & 108 & 129 \\
$0.8-1.6$ & 20 & - & 4 \\
$1.6-2.4$ & 2 & - & - \\
$2.4-3.2$ & 1 & - & - \\
$3.2-4.0$ & 0 & - & - \\
$4.0-4.8$ & 2 & - & - \\
$4.8-5.6$ & 4 & - & - \\
$5.6-6.4$ & 0 & - & - \\
$6.4-7.2$ & 1 & - & - \\
$7.2-8.0$ & 1 & - & - \\
Total ind. & 551 & 108 & 133 \\
\hline
\end{tabular}


The total coverage of individuals presented different values for each of the three sites (H1LF: 2,140.2 $\mathrm{m}^{2}$; H2MF: $4.73 \mathrm{~m}^{2}$ and H3SF: $258.3 \mathrm{~m}^{2}$ ).

\subsection{Environmental variables}

The canopy opening and litter deposition varied significantly. The numbers were greater in H3SF in relation to $\mathrm{H} 1 \mathrm{LF}$ and $\mathrm{H} 2 \mathrm{MF}$, the last two having registered statistically equivalent values. Photosynthetically active radiation differed in each of the three environments, being higher in H3SF and lower H2MF. Soil moisture was higher in H1LF compared to the other two sites (Table 2). The average temperature was not significantly different at the three sites, however, the average was lower mean $\mathrm{H} 1 \mathrm{LF}$, differing $1.87{ }^{\circ} \mathrm{C}$ from $\mathrm{H} 2 \mathrm{MF}$ and $0.94{ }^{\circ} \mathrm{C}$ from $\mathrm{H} 3 \mathrm{SF}$. In addition, the $\mathrm{H} 3 \mathrm{SF}$ registered a temperature $0.93{ }^{\circ} \mathrm{C}$ lower than that of $\mathrm{H} 2 \mathrm{MF}$.

The principal components analysis (PCA) identified the most important variables in the density-coverage relationship of $D$. sellowiana, evidencing the separation of the subplots of each site. There were only two components with eigenvalues greater than 1 . The first main component accounts for $38.7 \%$ of the total variation found, and of the six variables, three were positively related: plant cover (0.57) and soil moisture (0.52), associating the H1LF subplots (Figure 3). The lowest soil moisture and lowest plant cover in H2FM influenced the clustering of this site's subplots. The second main component accounts for $25.8 \%$ of the variation, in which all variables are positively

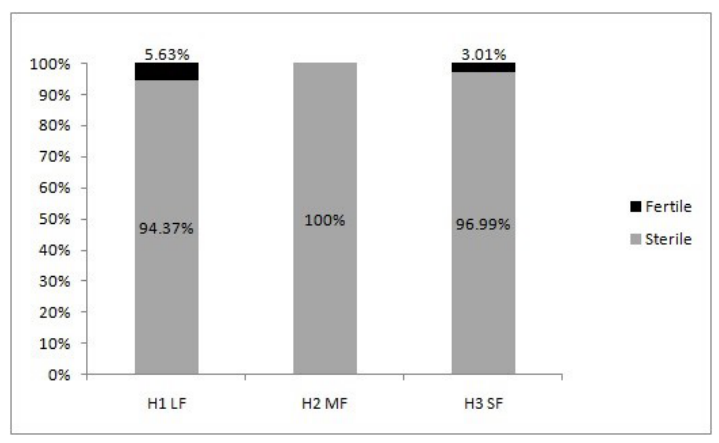

Figure 2. Distribution of fertile and sterile individuals of Dicksonia sellowiana Hook in three sites within an Araucaria Forest ( $\backsim$ Fertile, $\square$ Sterile). related. The canopy opening $(0.58)$, the photosynthetically active radiation $(0.57)$ and the litter $(0.54)$ were the most important to add portions of the H3SF.

\section{Discussion}

Our results demonstrate a significant structural distinction between the populations within each of the fragments with different sizes and intensities of use, although located geographically close to one another. The outcomes also reveal that the population of H1LF is one of the densest that has been described in southern Brazil. The total count of individuals in this site is higher than the one observed in the same forest type by Marques and Krupek (2014) (1,380 ind. ha $\left.{ }^{-1}\right)$, Blume et al. (2010) (1,430 ind. ha-1) and Senna (1996) who recorded 1,479 ind. ha-1. This statement considers surveys that include young individuals, with average caudice heights measured at ground level and density estimates for areas of 1 ha. The maximum density of 63 individuals per sampling unit in the H1LF evidences D. sellowiana as the predominant species in the forest physiognomy, which was also described by Senna (1996).

Soil moisture was the most influential variable in the high plant coverage in the H1LF, with a maximum number of $227.7 \mathrm{~m}^{2}$ in a single subplot, evidencing the high density of individuals, high aggregation index and leaf overlap in $100 \mathrm{~m}^{2}$ of sample area. The moisture condition is inherent to the development of this species, which, according to paleopalinological records from the Upper Holocene, is associated with the Araucaria Forest, initially, occupying the riparian forests (Behling et al., 2009).

In addition, individuals' height was higher in H1LF, the only site that was not limited to the first two size classes. For this result we considered that an adult individual of $8 \mathrm{~m}$ is approximately 142 years old, as according to Schmitt et al. (2009) the growth of the species is only $5.6 \mathrm{~cm}$ year $^{-1}$. This fact evidenced the great conservation and succession degree in this site. Tree ferns can be used as indicators of vegetation conservation (Castello et al., 2017) and successional stages of forests (Schmitt and Windisch, 2012).

In the H3SF sub-forest, the physiognomic aspect of predominance of the species is not evidenced. The total number of individuals corresponds to only $24.13 \%$ of those registered in H1LF, while the coverage of the plants represents

Table 2. Average values and standard deviation $( \pm$ ) for the coverage data of the species (SC), Photosynthetically Active Radiation (PAR), canopy opening (CO), soil moisture (SM), litter (LT) and temperature (T) for the three sites studied (H1LF, H2MF, H3SF) in Cambará do Sul, Rio Grande do Sul.

\begin{tabular}{cccccc}
\hline Variables & H1LF & H2MF & H3SF & Test & $\boldsymbol{P}$ \\
\hline CO $(\%)$ & $18.5 \pm 5.0^{\mathrm{b}}$ & $20.8 \pm 7.8^{\mathrm{b}}$ & $24.4 \pm 3.8^{\mathrm{a}}$ & $\mathrm{H}=18.4$ & $<\mathbf{0 . 0 0 1}$ \\
$\mathrm{SC}\left(\mathrm{m}^{2} \mathrm{plot}^{-1}\right)$ & $107 \pm 66.1^{\mathrm{a}}$ & $0.2 \pm 0.3^{\mathrm{c}}$ & $12.9 \pm 20.2^{\mathrm{b}}$ & $\mathrm{H}=45.2$ & $<\mathbf{0 . 0 0 1}$ \\
$\mathrm{LT}(\mathrm{cm})$ & $3.29 \pm 1.7^{\mathrm{b}}$ & $2.4 \pm 1.0^{\mathrm{b}}$ & $4.5 \pm 1.4^{\mathrm{a}}$ & $\mathrm{H}=18.5$ & $<\mathbf{0 . 0 0 1}$ \\
PAR $\left(\mu \mathrm{mol} \mathrm{s} \mathrm{m}^{-2}\right)$ & $74.5 \pm 66.4^{\mathrm{b}}$ & $23.9 \pm 13.6^{\mathrm{c}}$ & $237.3 \pm 236.3^{\mathrm{a}}$ & $\mathrm{H}=28.6$ & $<\mathbf{0 . 0 0 1}$ \\
$\mathrm{SM}(\%)$ & $48.8 \pm 10.7^{\mathrm{a}}$ & $31.9 \pm 7.6^{\mathrm{b}}$ & $38.1 \pm 6.7^{\mathrm{b}}$ & $\mathrm{F}=19.6$ & $<\mathbf{0 . 0 5}$ \\
$\mathrm{T}\left({ }^{\circ} \mathrm{C}\right)$ & $14.2 \pm 1.8^{\mathrm{a}}$ & $16.1 \pm 7.2^{\mathrm{a}}$ & $15.2 \pm 1.8^{\mathrm{a}}$ & $\mathrm{F}=1.1$ & $>0.05$ \\
\hline
\end{tabular}

H: Kruskal-Wallis; $P$ : significance. Different letters on the same line indicate a statistically significant difference at the $5 \%$ level by the Mann-Withney or Tuckey test. $P$ values in bold represent statistical differences. 


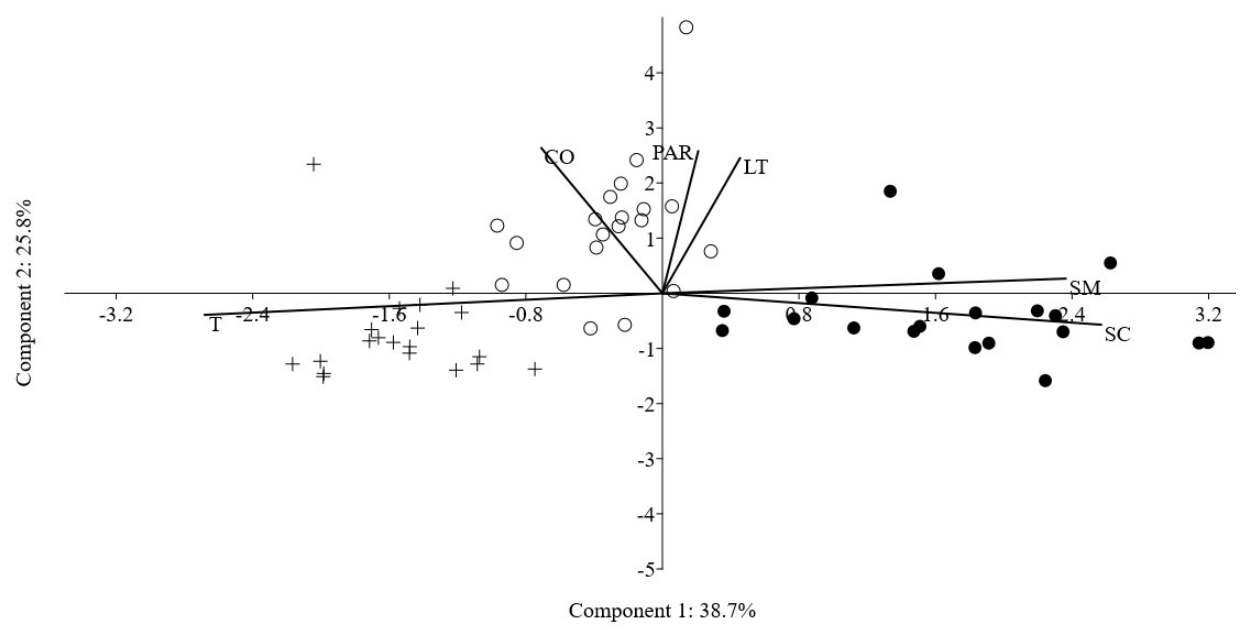

Figure 3. Principal Components Analysis (PCA), H1LF $(\bullet), \mathrm{H} 2 \mathrm{MF}(+)$ and H3SF $(\circ)$. SC: coverage of the species per plot; SM: soil moisture; CO: canopy opening; LT: litter; PAR: photosynthetically active radiation and T: temperature.

only $12 \%$ of that registered in H1LF, with a maximum of $71.8 \mathrm{~m}^{2}$ in a single sub-plot. This reduction in relation to H1LF was associated with significantly higher rates of canopy opening and PAR in H3SF. The records of higher coverage and density of individuals are from sites with lower insolation (Higuchi et al., 2013). The distribution of plants in H3SF is more homogeneous compared to H1LF, resulting in the lower pooling of individuals.

The higher canopy opening rates influenced soil moisture, which in H3SF is expressively lower than in H1LF, even under the same precipitation conditions. The low humidity is also determinant in the reduction of the litter decomposition rate (Bauer et al., 2016), which may explain the significant increase of this layer in the H3SF. These conditions in the H3SF could have deprived the colonization of the plants in relation to the other two sites.

However, H2MF recorded $19.6 \%$ of the total H1LF individuals and $83.7 \%$ of the total $\mathrm{H} 3 \mathrm{SF}$. The total cover of the plants represented only $0.2 \%$ relative to the large fragment and $1.8 \%$ to the small fragment. The difference is so pronounced that the lowest H1LF subplot has practically twice the coverage $\left(8.8 \mathrm{~m}^{2}\right)$ recorded in the sum of the 20 subplots of the H2MF $\left(4.7 \mathrm{~m}^{2}\right)$. This structure is expected, since the population of $\mathrm{H} 2 \mathrm{MF}$ is composed exclusively of individuals with a caudice of $5 \mathrm{~cm}$ height max. As H2MF was incorporated into the park unit only in 2001, the most recent impacts verified in this site may also have contributed to a reduction in the species' abundance and coverage. The traces of the extraction of adult specimens from the site indicate that spore banks originated the clusters of young plants that currently make up the population. The spores of $D$. sellowiana remained viable for 4.5 years (Begnini and Randi, 2010), thus indicating the resilience potential of the species and reinforcing the need for preservation of this forest fragment.

In addition, it is necessary to consider two aggravating factors for the susceptibility of the H2MF population: cattle grazing, which by trampling can damage or eliminate individuals due to reduced height, and the fact that $D$. sellowiana is vulnerable to the effects of global warming. Even in the most optimistic projections, there should be reductions of over $50 \%$ of the potential area for the species (Medeiros et al., 2013). The negative effects that temperature increases can cause in the species would probably be more expressive on the $\mathrm{H} 2 \mathrm{MF}$ population that already registers higher average temperatures than the other two sites. With the exception of temperature, none of the other factors explains the distribution of individuals in $\mathrm{H} 2 \mathrm{MF}$ subplots. Other studies with tree ferns have already attributed the differences in spatial distribution of the populations to microclimate conditions (Silva et al., 2011).

The spatial distribution of $D$. sellowiana in $\mathrm{H} 2 \mathrm{MF}$ (the most anthropized fragment) also evidences the initial phase of regeneration of the population, as even with a smaller number of individuals, aggregation index was higher than that registered in H1LF and H3SF. The lowest value was recorded in the smaller fragment and the intermediate pooling index was recorded in H1LF, which presents the most conserved interior. Intraspecific pooling intensity may be associated with several processes, such as the spatial structuring of microhabitats with conditions for spore germination and seedling development (Mallmann et al., 2013) and/or the greater probability of establishment nearer the mother plant due to the limitation of spore dispersion (Jones et al., 2007).

Many fern species studied in different forest formations presented an aggregate spatial distribution Mallmann et al. (2013), Franz and Schmitt (2005), Schmitt and Windisch $(2005,2007)$, Rechenmacher et al. (2007), which shows a tendency for this vegetal group.

Although our results demonstrate that conservation units do not offer full protection to the populations of D. sellowiana, their importance for the maintenance of the species is undeniable. Montagna et al. (2012) have 
shown that populations in conservation units maintain a greater genetic variability than other areas, confirming a better state of conservation of these populations. They also certified that good conservation strategies should include large numbers of populations. Therefore, the maintenance of the large fragment becomes paramount due to its advanced stage of regeneration. The condition of species threatened with extinction also emphasizes the conservation of MF and SF because they have established populations with a great potential for development.

\section{Final Considerations}

The analysis of the population structure of Dicksonia sellowiana is essential in the planning of actions for the conservation of Araucaria Forest fragments. This is mainly due to the fact that this species allows the intensity of anthropic interference to which the remnant was submitted to be evaluated. It is necessary to rethink the management policies in conservation units so that the laws are fully complied with and the species are effectively protected.

The sites presented different values of soil moisture, canopy opening, photosynthetically active radiation and litter thickness, which in turn suffer interference from forest fragmentation. These factors influenced the distribution and population structure of $D$. sellowiana, thus reiterating that forest fragmentation and/or anthropization has subsequent implications, whose effects are not easily measurable, predictable or identifiable.

\section{References}

BAUER, D., SANTOS, E.L. and SCHMITT, J.L., 2016. São Leopoldo: avaliação da decomposição de serapilheira em dois fragmentos de caatinga no sertão paraibano. Instituto Anchietano de Pesquisas. Botânica, vol. 69, pp. 307-318.

BECKER, D.F.P., MÜLLER, A. and SCHMITT, J.L., 2015. Influência dos forófitos Dicksonia sellowiana e Araucaria angustifolia sobre a comunidade de epífitos vasculares em Floresta com Araucária. Floresta, vol. 45, no. 4, pp. 781-790. http://dx.doi. org/10.5380/rf.v45i4.37082.

BEGNINI, R.M. and RANDI, A.M., 2010. Viabilidade de esporos de Dicksonia sellowiana Hook. (Cyatheales, Dicksoniaceae) e Rumohra adiantiformis (Forst.) Ching (Polypodiales, Dryopteridaceae). INSULA Revista de Botânica, vol. 38, pp. 15.

BEHLING, H., JESKE-PIERUSCHKA, J., SCHÜLER, L. and PILLAR, V.D.P., 2009. Dinâmica dos campos no sul do Brasil durante o Quaternário Tardio. In: V.P. PILLAR, S.C. MÜLLER, Z.M.S. CASTILHOS, A.V.A. JACQUES, eds. Campos Sulinos - conservação e uso sustentável da biodiversidade. Brasília: MMA, pp. 13-25.

BIONDI, D., LEAL, L., MARTINI, A. and NATAL, C.M., 2009. Caracterização dendrométrica de Dicksonia sellowiana Hook. em povoamento de Araucaria angustifolia (Bertol.) Kuntze. Cerne, vol. 15, pp. 4.

BLUME, M., RECHENMACHER, C. and SCHMITT, J.L., 2010. Padrão de distribuição espacial de samambaias no interior florestal do Parque Natural Municipal da Ronda, Rio Grande do Sul, Brasil. Pesquisas. Botanica, vol. 61, pp. 219-227.
CASTELlO, A.C.D., COELHO, S. and CARDOSO-LEITE, E., 2017. Lianas, tree ferns and understory species: indicators of conservation status in the Brazilian Atlantic Rainforest remnants, southeastern Brazil. Brazilian Journal of Biology $=$ Revista Brasileira de Biologia, vol. 77, no. 2, pp. 213-226. http://dx.doi. org/10.1590/1519-6984.07715. PMid:27579972.

CORRÊA, M.P., 1984. Dicionário de plantas úteis do Basil e das exóticas cultivadas. Imprensa Nacional, Brasil, vol. 2, pp. 209-210.

CORTEZ, L., 2001. Pteridofitas epifitas encontradas en cyatheaceae y dicksoniaceae de lós bosques nublados de Venezuela. Gayana. Botánica, vol. 58, no. 1, pp. 13-23. http://dx.doi.org/10.4067/ S0717-66432001000100002.

FRAGA, L.L., SILVA, L.B.D. and SCHMITT, J.L., 2008. Composição e distribuição vertical de pteridófitas epifíticas sobre Dicksonia sellowiana Hook. (Dicksoniaceae), em floresta ombrófila mista no sul do Brasil. Biota Neotropica, vol. 8, no. 4, pp. 123-128. http://dx.doi.org/10.1590/S1676-06032008000400011.

FRANZ, I. and SCHMITT, J.L., 2005. Blechnum brasiliense Desv. (Pteridophyta, Blechnaceae): Estrutura populacional e desenvolvimento da fase esporofítica. Pesquisas Botânica, vol. 56, pp. 173-183.

FUNDAÇÃO SOS MATA ATLÂNTICA, 2015 [viewed 11 July 2018]. Atlas dos Remanescentes Florestais da Mata Atlântica. [online]. São Paulo. Available from: http://mapas.sosma.org.br/dados.

FUNDAÇÃO ZOOBOTÂNICA DO RIO GRANDE DO SUL - FZB, 2014 [viewed 29 October 2017]. Lista de espécies da flora gaúcha ameaçadas de extinção [online]. Porto Alegre: Fundação Zoobotânica do Rio Grande do Sul. Available from: http://www.fzb.rs.gov.br/upload/2014090911580809092014esp eciesameacadas.pdf

GARCIA, L.C., REZENDE, M.Q., PIMENTA, M.A., MACHADO, R.M. and LEMOS-FILHO, J.P., 2007. Heterogeneidade do dossel e quantidade de luz no recrutamento do sub-bosque de uma mata ciliar no Alto São Francisco, Minas Gerais: análise através de fotos hemisféricas. Revista Brasileira de Biociências, Porto Alegre, vol. 5, no. 2, pp. 99-101.

GASPER, A.L.D., SEVEGNANI, L., VIBRANS, A.C., UHLMANN, A., LINGNER, D.V., VERDI, M., DREVECK, S., STIVAL-SANTOS, A., BROGNI, E., SCHMITT, R. and KLEMZ, G., 2011. Inventário de Dicksonia sellowiana Hook. em Santa Catarina. Acta Botanica Brasílica, vol. 25, no. 4, pp. 776-784. http://dx.doi.org/10.1590/S0102-33062011000400005.

HIGUCHI, P., SILVA, A.C.D., ALMEIDA, J.A.D., BORTOLUZZI, R.L.D.C., MANTOVANI, A., FERREIRA, T.D.S., SOUZA, S.T., GOMES, J.P. and SILVA, K.M., 2013. Florística e estrutura do componente arbóreo e análise ambiental de um fragmento de Floresta Ombrófila Mista Alto-montana no município de Painel, SC. Ciência Florestal, vol. 23, no. 1, pp. 153-164. http://dx.doi. org/10.5902/198050988449.

INSTITUTO BRASILEIRO DE GEOGRAFA E ESTATÍSTICA - IBGE, 2016 [viewed 14 July 2018]. Banco de dados agregados [online]. Available from: http://www.ibge.gov.br

JONES, M.M., OLIVAS ROJAS, P., TUOMISTO, H. and CLARK, D.B., 2007. Environmental and neighbourhood effects on tree fern distributions in a Neotropical lowland rain forest. Journal of Vegetation Science, vol. 18, no. 1, pp. 13-24. http:// dx.doi.org/10.1111/j.1654-1103.2007.tb02511.x.

KOCH, Z. and CORRÊA, M.C., 2002. Araucária: a floresta do Brasil Meridional. Curitiba: Olhar Brasileiro. 148 p. 
KREBS, C.J., 1989. Ecological methodology. Menlo Park: Addison Wesley Educational Publishers.

MALLMANN, I.T. and SCHMITT, J.L., 2014. Riqueza e composição florística da comunidade de samambaias na mata ciliar do rio Cadeia, Rio Grande do Sul, Brasil. Ciência Florestal, vol. 24, no. 1, pp. 97-109.

MALLMANN, I.T., ROCHA, L.D. and SCHMITT, J.L., 2013. Padrão de distribuição espacial de quatro espécies de samambaias em três fragmentos de mata ciliar do rio Cadeia, RS, Brasil. Revista Brasileira de Biociências, vol. 11, no. 2, pp. 139-144.

MANTOVANI, M., 2004. Caracterização de populações naturais de xaxim (Dicksonia sellowiana (Presl.) Hooker), em diferentes condições edafo-climáticas no estado de Santa Catarina. Florianópolis: Universidade Federal de Santa Catarina. Dissertação de Mestrado em Botanica.

MARQUES, M.M. and KRUPEK, R.A., 2014. Distribuição espacial e estrutura populacional de Dicksonia sellowiana Hook. em um fragmento de floresta ombrófila mista em União da Vitória, Paraná. Ambiência, vol. 10, pp. 351-362.

MEDEIROS, M.B.D., CARDOSO, M.S., ALBUQUERQUE, R.W. and NORONHA, S.E., 2013. Redução de incertezas em análise de vulnerabilidade às mudanças climáticas para Dicksonia sellowiana. Pesquisa Florestal Brasileira, vol. 33, no. 75, pp. 299-308. http://dx.doi.org/10.4336/2013.pfb.33.75.372.

MINISTÉRIO DO MEIO AMBIENTE - MMA, 2014. Lista oficial de espécies da Flora brasileira ameaçada de extinção. Diário Oficial da República Federativa do Brasil, Brasília, 24 setembro. Seção 1, no. 185 , pp. 75-83

MONTAGNA, T., FERREIRA, D.K., STEINER, F., FERNANDES, C.D., BITTENCOURT, R., SILVA, J.Z.D., MANTOVANI, A. and REIS, M.S.D., 2012. A importância das unidades de conservação na manutenção da diversidade genética de xaxim (Dicksonia sellowiana) no Estado de Santa Catarina. Biodiversidade Brasileira, vol. 2, no. 2, pp. 26-32.

NEGRÃO, R., SAMPAIO-E-SILVA, T., KORTZ, A.R., MAGURRAN, A. and MATOS, D.M.S., 2017. An endangered tree fern increases beta-diversity at a fine scale in the Atlantic Forest Ecosystem. Flora, vol. 234, pp. 1-6. http://dx.doi.org/10.1016/j. flora.2017.05.020

OLIVEIRA, V., ZUCHETTO, M., PAULA, C., VERDAM, M., CAMPOS, R., DUARTE, A., MIGUEL, O. and MIGUEL, O.G., 2015. Avaliação do potencial antioxidante frente à oxidação lipídica e da toxicidade preliminar do extrato e frações obtidas das frondes de Dicksonia sellowiana (Pres1.) Hook. Revista Brasileira de Plantas Medicinais, vol. 17, no. 4, pp. 614-621. http://dx.doi. org/10.1590/1983-084X/14_071.

OLIVEIRA, V.B., ZUCHETTO, M., MERINO, F.J.Z. and MIGUEL, O.G., 2013. Dicksonia sellowiana (Presl.) Hook, Dicksoniaceae a fern characteristic of mixed ombrophilous forest: a review. Visão Acadêmica, vol. 14, pp. 3.

PEEL, M.C., FINLAYSON, B.L. and MCMAHON, T.A., 2007. Updated world map of the Köppen Geiger climate classification. Hydrology and Earth System Sciences, vol. 11, no. 5, pp. 16331644. http://dx.doi.org/10.5194/hess-11-1633-2007.

RECHENMACHER, C., SCHMITT, J.L. and BUDKE, J.C., 2007. Estrutura e distribuição espacial de uma população de Blechnum tabulare (Thunb.) Kuhn (Pteridophyta, Blechnaceae) em um mosaico Floresta-Campo no Sul do Brasil. Pesquisas. Botânica, vol. 58, pp. 177-185.

RIO DE JANEIRO, 2016 [viewed 2 October 2017]. Flora do Brasil 2020 em construção [online]. Rio de Janeiro: Instituto de Pesquisas Jardim Botânico do Rio de Janeiro. Available from:
http://floradobrasil.jbrj.gov.br/reflora/listaBrasil/PrincipalUC/ PrincipalUC.do;jsessionid=00F5A48FF55DCFD089C88D33 E2534A1D

SCHMITT, J.L. and WINDISCH, P.G., 2005. Aspectos ecológicos de Alsophila setosa Kaulf. (Cyatheaceae, Pteridophyta) no Rio Grande do Sul, Brasil. Acta Botanica Brasílica, vol. 19, no. 4, pp. 859-865. http://dx.doi.org/10.1590/S0102-33062005000400021.

SCHMITT, J.L. and WINDISCH, P.G., 2007. Estrutura populacional e desenvolvimento da fase esporofítica de Cyathea delgadii Sternb. (Cyatheaceae, Monilophyta) no sul do Brasil. Acta Botanica Brasílica, vol. 21, no. 3, pp. 731-740. http://dx.doi. org/10.1590/S0102-33062007000300019.

SCHMITT, J.L. and WINDISCH, P.G., 2012. Caudex growth and phenology of Cyathea atrovirens (Langsd. \& Fisch.) Domin (Cyatheaceae) in secondary forest, southern Brazil. Brazilian Journal of Biology $=$ Revista Brasileira de Biologia, vol. 72, no. 2, pp. 397-405. http://dx.doi.org/10.1590/S1519-69842012000200023. PMid:22735150.

SCHMITT, J.L., SCHNEIDER, P.H. and WINDISCH, P.G., 2009. Crescimento do cáudice e fenologia de Dicksonia sellowiana Hook. (Dicksoniaceae) no sul do Brasil. Acta Botanica Brasílica, vol. 23, no. 1, pp. 289-291. http://dx.doi.org/10.1590/S010233062009000100030

SCHMITT, J.L., WINDISCH, P.G. and BUDKE, J.C., 2005. Aspectos florísticos e ecológicos de pteridófitas epifíticas em cáudices de Dicksonia sellowiana Hook. (Pteridophyta, Dicksoniaceae), São Francisco de Paula, RS, Brasil. Pesquisas Botânica, vol. 56, pp. 161-172.

SENNA, R.M., 1996. Pteridófitas no interior de uma floresta com araucária: composição florística e estrutura ecológica. Universidade federal do Rio Grande do Sul. Porto Alegre. Dissertação de Mestrado.

SILVA, I.A.A., PEREIRA, A.F.N. and BARROS, I.C.L., 2011. Edge effects on fern community in an Atlantic Forest remnant of Rio Formoso, PE, Brazil. Brazilian Journal of Biology $=$ Revista Brasileira de Biologia, vol. 71, no. 2, pp. 421-430. http://dx.doi. org/10.1590/S1519-69842011000300011. PMid:21755159.

STRECK, E.V., KÄMPF, N., DALMOLIN, R.S.D., KLAMT, E., NASCIMENTO, P.C., SCHNEIDER, P., GIASSON, E. and PINTO, L.F.S., 2008. Solos do Rio Grande do Sul. 2. ed. Porto Alegre: EMATER. 222 p.

TRYON, R.M. and TRYON, A.F., 1982. Ferns and allied plants with special reference to tropical America. New York: Springer Verlag. 857 p.

WEBER, F.S., LISBOA, G.D.S., UBERTI, G.M., LONGHI, S.J., STEPKA, T.F., KERVALD, L.A. and MIRANDA, D.L.C.D., 2015. Dinâmica e estrutura da espécie Dicksonia sellowiana Hook. em remanescente de Floresta Ombrófila Mista. Nativa (Sinop), vol. 3, no. 3, pp. 170-178. http://dx.doi.org/10.14583/2318-7670. v03n03a04.

WINDISCH, P.G., 2002. Pteridófitas do Brasil: diversidade decrescente. In: E.L. Araujo, A.N. Moura, E.V.S.B. Sampaio, L.M.S. Gestinari and J.M.T. Carneiro, eds. Biodiversidade, conservação e uso sustentável da flora do Brasil. Recife: Universidaade Federal Rural de Pernambuco e Sociedade Botânica do Brasil, pp. 196-198.

ZIEMMER, J.K., BEHLING, A. and CORTE, A.P.D., 2016. Quantificação da biomassa e dos teores de carbono de pteridófitas arborescentes em Floresta Ombrófila Mista. biofix Scientific Journal, vol. 1, no. 1., pp. 60-73. 